\title{
Effect of cobalt chloride on soybean seedlings subjected to cadmium stress
}

\author{
Jagna Chmielowska-Bąk ${ }^{1 *}$, Isabelle Lefèvre ${ }^{2}$, Stanley Lutts ${ }^{2}$, Agata Kulik' ${ }^{1}$, Joanna Deckert ${ }^{1}$ \\ ${ }^{1}$ Department of Plant Ecophysiology, Institute of Experimental Biology, Faculty of Biology, Adam Mickiewicz University, Umultowska 89, 61-614 Poznań, Poland \\ ${ }^{2}$ Groupe de Recherche en Physiologie végétale (GRPV), Earth and Life Institute, Université catholique de Louvain, Croix du Sud, 4-5, bte L7.07.13, 1348 Louvain-la-Neuve, Belgium
}

\begin{abstract}
Contamination of the environment with heavy metals such as $\mathrm{Cd}$ is a serious problem of modern world. Exposure of plants to Cd leads to oxidative stress, inhibition of respiration and photosynthesis, increased rate of mutation and, as a consequence, stunted growth and yield decrease. One of the common reactions of plants to cadmium stress is over-production of ethylene, however the exact role of this hormone in plants response to $\mathrm{Cd}$ is still unrecognized. The aim of the present study is evaluation of the impact of an ethylene synthesis inhibitor, Co, on the response of soybean seedlings to cadmium stress. The experiments included measurements of growth, cell viability, ethylene production and expression of genes associated with cellular signaling in soybean seedlings exposed to $\mathrm{CdCl}_{2}$ (with $\mathrm{Cd}$ in a concentration of $223 \mu \mathrm{M}$ ) and/or $\mathrm{CoCl}_{2}$ (with Co in concentration of $4.6 \mu \mathrm{M}$ ). Surprisingly, the results show that Co has no effect on ethylene biosynthesis, however, it affects cell viability and expression of $\mathrm{Cd}$-induced genes associated with plant signaling pathways. The affected genes encode mitogen-activated protein kinase kinase2 (MAPKK2), nitrate reductase and DOF1 and bZIP2 transcription factors. The role of Co in plants response to cadmium stress and its potential use as an ethylene inhibitor is discussed.
\end{abstract}

Keywords: cobalt; heavy metal; gene expression; signaling; Glycine max

\section{Introduction}

Contamination of the environment with heavy metals, including $\mathrm{Cd}$, is a serious problem of the modern world. Cadmium toxicity in plants leads to the generation of oxidative stress, chlorosis, inhibition of photosynthesis, disturbances in mineral homeostasis, increased rate of mutations and initiation of apoptotic and necrotic processes [1-3]. The described toxic symptoms lead to inhibition of plants growth and decrease in the obtained yield. Moreover, $\mathrm{Cd}$ might accumulate in crop plants and enter human organisms through the food chain [4]. One of the common responses of plants to cadmium stress is enhanced production of ethylene [5-8]. However, the exact role of the observed Cd-dependent induction of this hormone's production is still unrecognized. It is known that ethylene constitutes an important stress-related signaling molecule [9]. There are individual reports stating that it mediates $\mathrm{Cd}$-dependent growth inhibition, hydrogen peroxide accumulation and programmed cell death (PCD) [7,10-12]. In mustard plants ethylene has been shown to participate in sulfur dependent alleviation of Cd toxicity through stimulation of antioxidant system $[7,13]$.

* Corresponding author. Email: jagna_c20@wp.pl

Handling Editor: Grażyna Kłobus
Due to the important role of ethylene in flowering, fruit ripening and response of plants to stress factors several inhibitors of its synthesis and perception were developed. One of the commonly used inhibitor is Co, which affects the activity of a key enzyme in ethylene's biosynthesis pathway - 1-aminocyclopropane-1-carboxylic acid oxidase (ACO) [14]. However, although relatively low concentration of Co might be beneficial for plants, higher concentrations exhibit toxic effect $[15,16]$. This metal has been shown to inhibit plants growth, cause oxidative stress, DNA damage and disturbances in photosynthesis [16-20]. Excess of Co also leads to alterations in germination, sex ratio, photoperiodism and uptake of other elements [16].

In the previous study we have shown that cadmium stress causes induction of ethylene biosynthesis and elevated expression of several genes associated with signaling pathways. Interestingly the promoters of $\mathrm{Cd}$-induced genes contained cis-acting elements connected with ethylene signaling [6]. The aim of present study was to investigate the effect of $\mathrm{Co}$, as a potential ethylene inhibitor, on soybean seedlings subjected to short term cadmium stress. The conducted research includes evaluation of the impact of Co on soybean growth parameters, viability, ethylene production and expression of six Cd-induced genes. 


\section{Material and methods}

\section{Plant material, growth conditions and treatment procedures}

If not stated differently the reagents were purchased at Sigma-Aldrich company (St. Louis, Missouri, USA). The applied growth conditions, $\mathrm{Cd}$ and Co concentrations and treatment periods were based on previous studies [6,21].

Soybean (Glycine max L cv. Nawiko) seeds were surface sterilized with $75 \%$ ethanol for $5 \mathrm{~min}$ and for $10 \mathrm{~min}$ with $1 \%$ sodium hyperchlorite. Seeds were washed for $30 \mathrm{~min}$, soaked in distilled water for $2 \mathrm{~h}$ and germinated on Petri dishes with moistened blotting paper for $48 \mathrm{~h}$. Germinated seedlings were transferred to new Petri dishes and treated with $5 \mathrm{ml}$ of either: distilled water (control), $4.6 \mu \mathrm{M}$ Co in $\mathrm{CoCl}_{2}$ solution (corresponding $10 \mu \mathrm{M} \mathrm{CoCl}_{2}$ ), $223 \mu \mathrm{M} \mathrm{Cd}$ in $\mathrm{CdCl}_{2}$ solution (corresponding to $25 \mathrm{mg} \mathrm{l}^{-1}$ ) or combined $\mathrm{Cd}$ and $\mathrm{Co}$ (corresponding to $4.6 \mu \mathrm{M}$ and $223 \mu \mathrm{M}$ respectively). After 3 and 6 hours of treatment seedlings root tips (100 mg) were cut off and frozen in $-80^{\circ} \mathrm{C}$ for RNA isolation. Due to the lack of significant effect in shorter treatment periods (data not shown) the measurements of roots growth and cell viability were carried out after 24 hours.

If not stated differently the measurements were performed on samples from 3 independent experimental repetitions, each sample consisted of a pool of 20 seedlings.

\section{Measurements of growth parameters}

After 24 hours of treatment the roots of soybean seedlings were straightened and their length was measured with the use of ruler. The fresh and dry weight of roots was measured on the WPS60/C scale (RadWag, Radom, Poland). The fresh weight was evaluated immediately after cutting off, while the dry weight was measured after $72 \mathrm{~h}$ of incubation at $55^{\circ} \mathrm{C}$.

\section{Estimation of cell viability}

The measurements of cell death were carried out according to the modified method described by Lehotai et al. [22]. After 24 hours of treatment with appropriate solutions root tips (200 mg) of soybean seedlings were cut off and incubated $20 \mathrm{~min}$ in $0.25 \%$ Blue Evans solution. Root tips were washed 3 times with distilled water and homogenized with $1.2 \mathrm{ml}$ of $1 \%$ of SDS dissolved in $50 \%$ ethanol. The samples were incubated for $15 \mathrm{~min}$ at $50^{\circ} \mathrm{C}$ and centrifuged $15 \mathrm{~min}$ at $12000 \mathrm{~g}$. The absorbance of supernatant was measured with Biomate $3 \mathrm{~S}$ spectrophotometer (Thermo Scientific, Waltham, USA) at $\lambda=600 \mathrm{~nm}$.

\section{Measurements of ethylene biosynthesis}

The ethylene production was measured with the use of ethylene detector ETD-300 (Sensor Sense, Nijmegen, The Netherlands). Soybean seedlings were placed in Petri dishes on two layers of filter paper moistened with $5 \mathrm{ml}$ of either distilled water (control), $4.6 \mu \mathrm{M}$ Co in $\mathrm{CoCl}_{2}$ solution, $223 \mu \mathrm{M} \mathrm{Cd}$ in $\mathrm{CdCl}_{2}$ solution or combined $\mathrm{Cd}$ and $\mathrm{Co}$ (corresponding to $4.6 \mu \mathrm{M}$ and $223 \mu \mathrm{M}$, respectively). The bottom part of the dish was covered with a Plexiglas plate with an inlet and outlet for gas flow, and tightly closed. The flow from each cuvette was directed into a photoacoustic cell where ethylene was quantified. The measurements were conducted in the dark during 24 hours, in stop-and-flow mode, with each cuvette being alternatively flushed with a flow of $3 \mathrm{l} \mathrm{h}^{-1}$. The amount of produced ethylene was detected every 12 minutes. As a control from the obtained emission rates the levels of ethylene in a cuvette containing moistened filter papers without seedlings was also measured. A detailed description of the system has been given previously [23]. The obtained results were analyzed with the use of Valve Controller software and expressed as nl per hour per $1 \mathrm{~g}$ of roots fresh weight. Measurements were performed on samples from 3 independent experimental repetitions; each sample consisted of a pool of 10 seedlings.

\section{Measurements of genes expression}

The RNA was isolated from $100 \mathrm{mg}$ of frozen root tips with the use of TriReagent according to the manufacture's instructions. The concentration of the obtained RNA was evaluated on NanoCell Accessory coupled with spectrophotometer Biomate $3 \mathrm{~S}$ (Thermo Scientific, Waltham, USA).

For the reverse transcription $1 \mu \mathrm{g}$ of RNA was purified with Deoxyribonuclease Kit and processed with the use of Reverse Transcription Kit (Thermo Scientific Fermentas, Waltham, USA): incubated with $1 \mu \mathrm{l}$ oligo dT $(100 \mu \mathrm{M}, 0.5$ $\mu \mathrm{g} / \mu \mathrm{l})$ at $65^{\circ} \mathrm{C}$ for $5 \mathrm{~min}$ followed by the incubation with $4 \mu \mathrm{l}$ of $5 \times$ Reaction Buffer, $1 \mu$ l of RiboLock ${ }^{\mathrm{TN}}$ RNase Inhibitor $(20 \mathrm{u} / \mu \mathrm{l}), 2 \mu \mathrm{l}$ of $10 \mathrm{mM}$ dNTP Mix and $1 \mu \mathrm{l}$ of RevertAid ${ }^{\mathrm{mm}}$ Reverse Transcriptase at $42^{\circ} \mathrm{C}$ for $10 \mathrm{~min}$. The reaction was stopped by incubation at $70^{\circ} \mathrm{C}$ for $10 \mathrm{~min}$. The obtained cDNA was diluted $5 \times$.

The measurements of genes expression were carried out with the use of real-time PCR reaction performed on RotorGene 6000 Thermocycler (Qiagen, Venlo, The Netherlands). The primers (listed in Tab. 1) were designed on the basis of sequences accessible in Soybase.org with the use of Primer3 software (http://bioinfo.ut.ee/primer3-0.4.0/). The reaction mixture contained $0.1 \mu \mathrm{M}$ of each primer, $1 \mu \mathrm{l}$ of diluted cDNA, $10 \mu$ of Power SYBR Green PCR Master Mix (Applied Biosystems, Foster City, California, USA) and DEPC treated water (BioShop, Burlington, Canada) to the total volume of $20 \mu \mathrm{l}$. The real-time PCR reaction started with initial denaturation at $95^{\circ} \mathrm{C}$ for $5 \mathrm{~min}$, followed by 13 cycles of touchdown PCR $\left(15 \mathrm{~s}\right.$ at $95^{\circ} \mathrm{C}, 20 \mathrm{~s}$ at $68^{\circ} \mathrm{C}$ decreasing by $1^{\circ} \mathrm{C}$ each cycle and $30 \mathrm{~s}$ at $72^{\circ} \mathrm{C}$ ) and 45 cycles of $10 \mathrm{~s}$ at $95^{\circ} \mathrm{C}$, $20 \mathrm{~s}$ at $55^{\circ} \mathrm{C}$ and $30 \mathrm{~s}$ at $72^{\circ} \mathrm{C}$. The reaction was finalized by denaturation at a temperature rising from $72^{\circ} \mathrm{C}$ to $95^{\circ} \mathrm{C}$ by one degree every $5 \mathrm{~s}$.

The relative gene expression was calculated with the use of Pfaffl equation [24] based on the efficiency and Ct values determined by Real-time PCR Miner [25]. Ubiquitin was chosen as reference gene. Measurements were performed on samples from 2-3 independent experimental repetitions; each sample consisted of a pool of 20 seedlings.

\section{Statistical analysis}

For evaluation of statistically significant differences the obtained data was analyzed with the use of ANOVA $(\alpha=0.05)$. In the case of the measurements of genes expression, due to the non-normal distribution of data, Mann-Whitney $U$ post-hoc test has been used. In all the other cases Scheffe's test has been applied. Results, which showed no statistically significant differences, are marked with the same letter. 
Tab. 1 Sequences of primers used for the real-time PCR reaction.

\begin{tabular}{|c|c|c|}
\hline Gene number in Soybase.org & Primers & Encoded protein \\
\hline Glyma05g37410 & $\begin{array}{l}\text { Left: TGTGCTATGCCAACATGGAT } \\
\text { Right: GAGGTATGGGGGAGTGAGGT }\end{array}$ & 1-aminocyclopropane-1-carboxylate synthase (ACS) \\
\hline Glyma17g06020 & $\begin{array}{l}\text { Left: AGCAGGTGCTGAAGGGTCTA } \\
\text { Right: TTCCTGGCTTCCATTGATTC }\end{array}$ & mitogen-activated protein kinase kinase 2 (MAPKK2) \\
\hline Glyma13g02510 & $\begin{array}{l}\text { Left: AAATCCCATGCAAGCTCATC } \\
\text { Right: GGTGCACCCCTTTGAAGTAA }\end{array}$ & nitrate reductase (NR) \\
\hline Glyma13g42820 & $\begin{array}{l}\text { Left: AAGCCAAAACTTGGAGCAGA } \\
\text { Right: CCTTGTCGACGGAGGAATTA }\end{array}$ & DOF1 transcription factor \\
\hline Glyma11g11450 & $\begin{array}{l}\text { Left: GAATCGACCCTGCAACTCAT } \\
\text { Right: ACCCAAACTGCAAACGAAAC }\end{array}$ & MYBZ2 transcription factor \\
\hline Glyma06g08390 & $\begin{array}{l}\text { Left: GCCCCATTGCTGTTCCTCATGT } \\
\text { Right: GCTGAGACTGGGCTCCCAACA }\end{array}$ & bZIP62 transcription factor \\
\hline Glyma20g27950 & $\begin{array}{l}\text { Left: GAAGTCGAAAGCTCCGACAC } \\
\text { Right: TGTT TTGGGAACACATCCAA }\end{array}$ & ubiquitin - reference gene \\
\hline
\end{tabular}

\section{Results}

Treatment with Cd for 24 hours caused inhibition of roots length and dry weight (Tab. 2). In turn Co had no effect on any of the growth parameters. At this time point there were also no differences in the viability of cells in the roots of control seedlings and seedlings treated with Co (Fig. 1). However, treatment with Cd caused increase in the Evans Blue uptake providing a significant increase in cells mortality. The cells mortality increased even stronger in the case of the roots of seedlings treated simultaneously with $\mathrm{Cd}$ and $\mathrm{Co}$.

Tab. 2 Growth parameters of the roots of soybean seedlings.

\begin{tabular}{lccc}
$\begin{array}{l}\text { Experimental } \\
\text { variant }\end{array}$ & $\begin{array}{c}\text { Roots length } \\
(\mathbf{m m})\end{array}$ & $\begin{array}{c}\text { Roots fresh } \\
\text { weight }(\mathbf{m g})\end{array}$ & $\begin{array}{c}\text { Roots dry } \\
\text { weight }(\mathbf{m g})\end{array}$ \\
\hline Control & $43 \pm 1^{\mathrm{a}}$ & $54 \pm 4^{\mathrm{a}}$ & $2.9 \pm 0.2^{\mathrm{a}}$ \\
$\mathrm{CoCl}_{2}$ & $47 \pm 5^{\mathrm{a}}$ & $62 \pm 8^{\mathrm{a}}$ & $3.3 \pm 0.3^{\mathrm{a}}$ \\
Cadmium & $30 \pm 2^{\mathrm{b}}$ & $53 \pm 3^{\mathrm{a}}$ & $2.7 \pm 0.1^{\mathrm{b}}$ \\
Cadmium $+\mathrm{CoCl}_{2}$ & $28 \pm 1^{\mathrm{b}}$ & $50 \pm 3^{\mathrm{a}}$ & $2.7 \pm 0.2^{\mathrm{b}}$ \\
\hline
\end{tabular}

The results are means of 3 independent experiments $\pm S E$. Results which showed no statistically significant differences are marked with the same letter ( $a$ or $b)$.

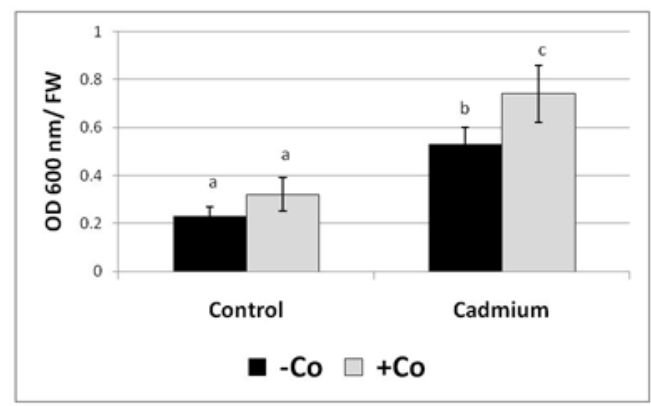

Fig. 1 Mortality of cell of soybean seedling roots represented as uptake of Evans Blue dye. The results are means of 4 independent experiments $\pm S E$. Results, which showed no statistically significant differences, are marked with the same letter ( $a, b$ or $c)$.
Application of Cd lead to augmented ethylene biosynthesis starting from the 5 th hour of treatment (Fig. 2). After $24 \mathrm{~h}$ the levels of ethylene were four times higher in the roots of seedlings exposed to $\mathrm{Cd}$ than in the roots of control seedlings and reached $8 \mathrm{nl} / \mathrm{h} \times$ fresh weight. Co had no significant effect on ethylene production neither in control nor Cd-treated seedlings.

Accordingly to our previous study [6] treatment with $\mathrm{CdCl}_{2}$ for $3 \mathrm{~h}$ caused increase in the expression levels of genes encoding aminocyclopropane-1-carboxylic acid synthase (ACS), mitogen-activated kinase kinase2 (MAPKK2) and DOF1 and MYBZ2 transcription factors (Fig. 3). Present research shows that $\mathrm{Co}$ diminished the $\mathrm{Cd}$-dependent induction of MAPKK2 and DOF1 expression (Fig. 3b,c).

Longer $(6 \mathrm{~h})$ exposure to $\mathrm{Cd}$ resulted in elevated levels of mRNA encoding nitrate reductase (NR), ACS and MYBZ2 and bZIP62 transcription factors (Fig. 4). Co caused augmentation of Cd-dependent induction of NR gene (Fig. 4b) and the same time decrease in Cd-dependent stimulation of gene encoding bZIP62 transcription factor (Fig. 4d).

\section{Discussion}

Although Cd caused significant reduction of roots length and dry weight after 24 hours of application, Co did not affect any of the measured growth parameters (Tab. 2). Treatment with $\mathrm{Cd}$ also led to the increase in the amount of dead cells in the roots soybean seedlings (Fig. 1). Application of Co additionally increased Cd toxicity as the amount of dead cells was significantly higher in seedlings treated with both Co and Cd than in the seedlings treated with only Cd (Fig. 1). Co is known to have beneficial effects on plant growth at moderate levels [15], however, it is possible that the combined effect of Co and Cd leads to the aggravation of the metals' toxicity. Indeed, combination of $\mathrm{Cu}$ and $\mathrm{Zn}$ was shown to be more toxic to black lentil than the separate effect of both heavy metals, while combined $\mathrm{Cd}$ and $\mathrm{Pb}$ stress was found to be more harmful to mustard plants than application of $\mathrm{Cd}$ or $\mathrm{Pb}$ alone [26,27]. In higher concentrations Co is toxic. It was shown to inhibit plants growth, germination rate, cause leaf fall, hamper photosynthesis and respiration and lead 


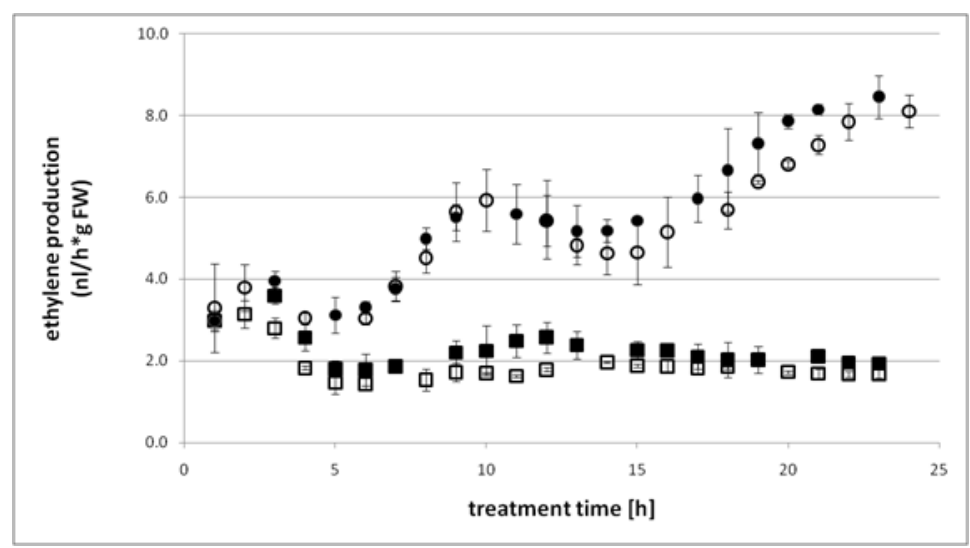

Fig. 2 Production of ethylene in roots of control soybean seedlings (dark square), seedlings treated with Co (light square), seedlings treated with $\mathrm{Cd}$ (dark circle) and seedlings treated with $\mathrm{Cd}$ and Co (light circle). The ethylene production is presented in nanoliters per hour in one gram of roots fresh weight. The results are means of 3 independent experiments $\pm S E$.

to DNA damage as well as decrease in RNA levels [16-20]. One admitted function of Co is to impair ethylene synthesis at various concentrations, treatment durations and plant species, by inhibiting ACC oxidase [28-32]. Surprisingly in the applied experimental conditions Co had no effect on hormones production (Fig. 2). It is possible that the inhibitory action of Co requires longer treatment periods or higher concentrations. Indeed, in the majority of studies performed by other researchers Co was applied for several days [28,30-32]. In the research conducted by Koehl et al. [29] tobacco suspension culture was also treated with Co for short time periods (3, 9 and $24 \mathrm{~h}$ ), however, the applied $\mathrm{CoCl}_{2}$ concentration was much higher $(100 \mu \mathrm{M})$ and the inhibitory effect on ethylene biosynthesis was noticed only after $9 \mathrm{~h}$ of treatment [29]. It is also possible that ethylene is synthesized without the participation of ACC oxdiase a target gene for Co inhibitory action. It has been shown that ACC might be oxidized nonenzymatically through superoxide anion generated in response to wounding [33].

In our previous study we have demonstrated that $\mathrm{Cd}$ causes induction of several genes associated with plant signaling pathways [6]. Application of $\mathrm{Cd}$ for $3 \mathrm{~h}$ induced expression of genes encoding 1-aminocyclopropane-1-carboxylic acid synthase (ACS), mitogen-activated kinase kinase2 (MAPKK2) and DOF1 and MYBZ2 transcription factors, while $6 \mathrm{~h}$ long treatment led to the increase in the expression of nitrate reductase (NR), ACS, MYBZ2 and bZIP62 genes. In the present study the influence of Co on the expression of mentioned, signaling associated genes after the same treatment has been evaluated.

Interestingly the results of present research show that Co influences expression of a key enzyme engaged in ethylene synthesis: 1-aminocyclopropane-1-carboxylic acid synthase. The genes expression was slightly repressed after $3 \mathrm{~h}$ (Fig. 3a)

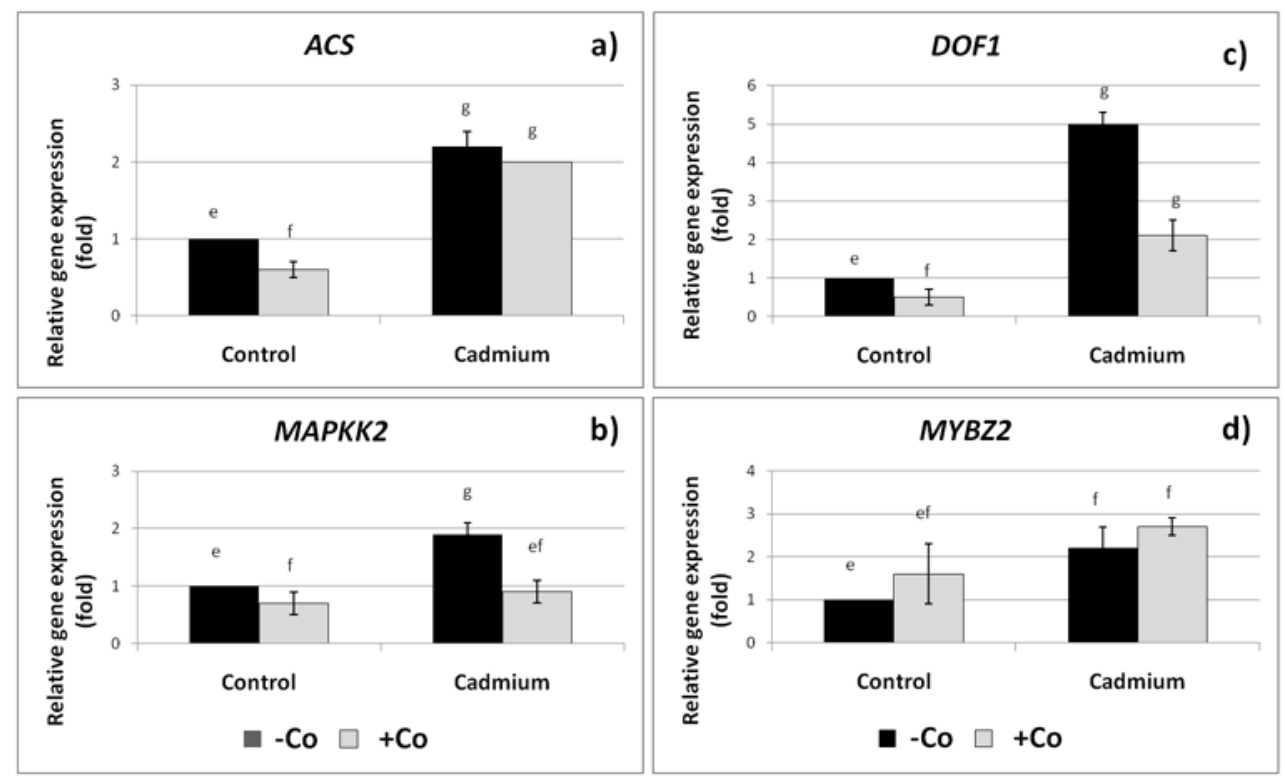

Fig. 3 Relative expression of gene encoding 1-aminocyclopropane-1-carboxylic acid synthase (a), mitogen-activated kinase kinase2 (b), DOF1 transcription factor (c) and MYBZ2 transcription factor (d) in soybean seedlings treated with appropriate solutions for $3 \mathrm{~h}$. The results are the means of 2-3 independent experiments $\pm S E$. Results, which showed no statistically significant differences, are marked with the same letter (e, for $g$ ). 


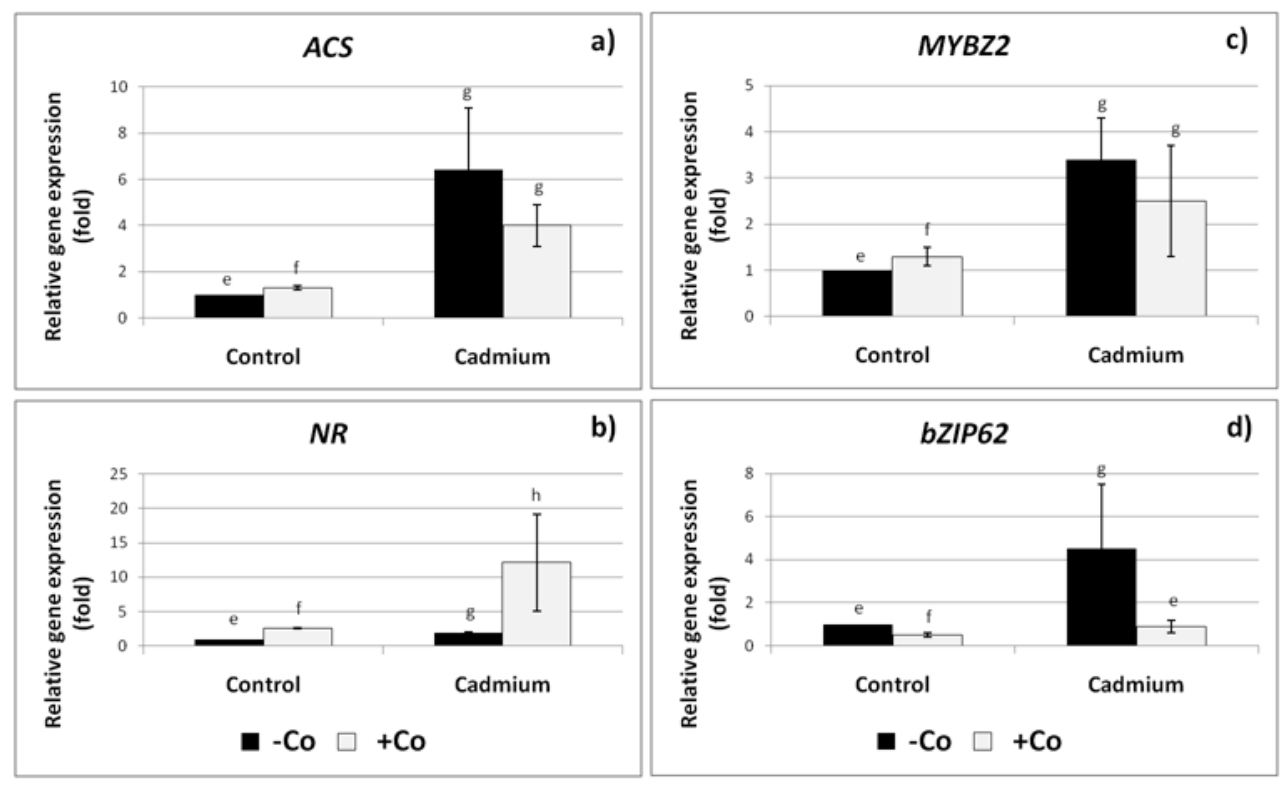

Fig. 4 Relative expression of gene encoding 1-aminocyclopropane-1-carboxylic acid synthase (a), nitrate reductase (b), MYBZ2 transcription factor (c) and bZIP62 transcription factor (d) in soybean seedlings treated with appropriate solutions for $6 \mathrm{~h}$. The results are the means of 2-4 independent experiments \pm SE. Results, which showed no statistically significant differences, are marked with the same letter (e, f, g or h).

and up-regulated after $6 \mathrm{~h}$ of treatment (Fig. 4a). Therefore it is possible that Co affects ethylene biosynthesis not solely by inhibiting ACC oxidase.

The obtained results also show that Co reversed the Cddependent induction of genes encoding MAPKK2 (Fig. 3b) and DOF1 transcription factor (Fig. 3c) after $3 \mathrm{~h}$ as well as gene encoding bZIP62 transcription factor (Fig. 4d) after $6 \mathrm{~h}$ of treatment. A possible explanation of the described phenomenon is the inhibitory effect of Co on Cd uptake. Indeed, Co was shown to reduce Cd uptake in bush beans and green alga Chlamydomonas reinhardatii $[16,34]$. However, in the referenced experiments the treatment times were much longer (21 and 60 days respectively). In the present study Co was applied for short time $(3,6$ or $24 \mathrm{~h})$ and even after $24 \mathrm{~h}$ did not reverse the $\mathrm{Cd}$-dependent inhibition of roots growth (Tab. 2). Moreover, application of Co for $24 \mathrm{~h}$ led to the intensification of Cd toxicity expressed by higher cells mortality (Fig. 1). Therefore, it is unlikely that Co caused a significant reduction of $\mathrm{Cd}$ uptake. The measurements of genes expression also showed that, after $6 \mathrm{~h}$ of treatment Co led to strong augmentation of Cd-dependent induction of NR gene (Fig. 4b).

The impact of Co on the expression of analyzed genes might lead to altered Cd sensing. There are several reports implying that MAPK cascades are involved in the transduction of Cd signals. Stimulation of various MAPKs by Cd has been observed in rice, alfalfa and Arabidopsis plants. Moreover, MPK6 identified in Arabidopsis plants, was shown to participate in Cd-dependent initiation of programmed cell death (PCD) [10,35-38]. Therefore, observed in the present research alterations in $M A P K K 2$ expression in response to Co might lead to disorders in the transduction of Cd signal and contribute to exacerbation of $\mathrm{Cd}$ toxicity.
There are reports stating that both applied metals, Cd and Co, cause inhibition of nitrate reductase activity after long treatment times [17,39-41]. Interestingly, the present study shows that short-term cadmium stress causes induction of $N R$ gene, which is strongly augmented by Co (Fig. 4b). Nitrate reductase is an important enzymes engaged in nitrogen metabolism - it catalyses reduction of nitrates to nitrites [42]. Therefore, the observed stimulation of $N R$ expression might constitute a defense mechanism, which aims to sustain nitrogen homeostasis. Nitrate reductase is also one of the enzymes engaged in $\mathrm{NO}$ formation [42]. Accumulation of $\mathrm{NO}$ in response to $\mathrm{Cd}$ has been observed in various plant species [43], however, its role is still debatable. The treatment with nitric oxide donor, SNP, caused attenuation of chlorophyll degradation and oxidative stress in plant exposed to Cd [44,45]. Nitric oxide also mediates induction of several signaling associated genes in response to short-term cadmium stress [46]. On the other hand NO contributes to Cd toxicity through increase in Cd uptake [1,47]. The observed Co-dependent induction of $N R$ gene might lead to over-production of NO, however, the exact role of such induction would need further investigation.

Increase in DOF1 and bZIP62 mRNA levels in response to Cd [6] and the fact that DOF1 was induced by drought stress in amaranth roots and bZIP62 conferred tolerance to low temperatures and salt stress in transgenic Arabidopsis plants, suggests that both transcription factors are involved in the regulation of genes expression under various stress conditions $[48,49]$. Therefore, observed in the present study Co-dependent decrease in DOF1 and bZIP62 expression might lead to alterations in the expression pattern of Cdresponsive genes. 
It can be concluded that Co may increase $\mathrm{Cd}$ toxicity, at least partly, through alterations in MAPK and NO signaling as well as disorders in regulation of genes expression mediated by DOF1 and bZIP62 transcription factors. The observed effects are independent from ethylene action.

\section{Acknowledgments}

The project was financed by National Science Center granted on the basis of decision number DEC-2011/03/N/NZ9/00214. The first author is a scholarship holder within the project "Scholarship support for Ph.D. students specializing in majors strategic for Wielkopolska's development", Sub-measure 8.2.2 Human Capital Operational Programme, co-financed by European Union under the European Social Fund. This work was also supported by the Fonds National de la Recherche Scientifique (FNRS, Belgium; conventions Nos. 1.5117.11 and 1.5114.11).

\section{Authors' contributions}

The following declarations about authors' contributions to the research have been made: designed the experiments: JD, JCB; supervised the research: JD, SL; conducted the experiments: JCB, AK; analyzed the results: JCB, IL; wrote the manuscript: JCB; revised the manuscript: JD, SL, IL.

\section{References}

1. Arasimowicz-Jelonek M, Floryszak-Wieczorek J, Deckert J, RucińskaSobkowiak R, Gzyl J, Pawlak-Sprada S, et al. Nitric oxide implication in cadmium-induced programmed cell death in roots and signaling response of yellow lupine plants. Plant Physiol Biochem. 2012;58:124134. http://dx.doi.org/10.1016/j.plaphy.2012.06.018

2. Nedjimi B, Daoud Y. Cadmium accumulation in Atriplex halimus subsp. schweinfurthii and its influence on growth, proline, root hydraulic conductivity and nutrient uptake. Flora. 2009;204(4):316-324. http://dx.doi.org/10.1016/j.flora.2008.03.004

3. Sun Z, Wang L, Chen M, Wang L, Liang C, Zhou Q, et al. Interactive effects of cadmium and acid rain on photosynthetic light reaction in soybean seedlings. Ecotoxicol Env Saf. 2012;79:62-68. http://dx.doi. org/10.1016/j.ecoenv.2011.12.004

4. Yang Y, Li F, Bi X, Sun L, Liu T, Jin Z, et al. Lead, zinc, and cadmium in vegetable/crops in a zinc smelting region and its potential human toxicity. Bull Env Contam Toxicol. 2011;87(5):586-590. http://dx.doi. org/10.1007/s00128-011-0388-7

5. Arteca RN, Arteca JM. Heavy-metal-induced ethylene production in Arabidopsis thaliana. J Plant Physiol. 2007;164(11):1480-1488. http:// dx.doi.org/10.1016/j.jplph.2006.09.006

6. Chmielowska-Bąk J, Lefèvre I, Lutts S, Deckert J. Short term signaling responses in roots of young soybean seedlings exposed to cadmium stress. J Plant Physiol. 2013;170(18):1585-1594. http:// dx.doi.org/10.1016/j.jplph.2013.06.019

7. Masood A, Iqbal N, Khan NA. Role of ethylene in alleviation of cadmium-induced photosynthetic capacity inhibition by sulphur in mustard: Ethylene in S-mediated alleviation of Cd stress. Plant Cell Env. 2012;35(3):524-533. http://dx.doi. org/10.1111/j.1365-3040.2011.02432.x

8. Rodriguez-Serrano M, Romero-Puertas MC, Zabalza A, Corpas FJ, Gomez M, Del Rio LA, et al. Cadmium effect on oxidative metabolism of pea (Pisum sativum L.) roots. Imaging of reactive oxygen species and nitric oxide accumulation in vivo. Plant Cell Env. 2006;29(8):15321544. http://dx.doi.org/10.1111/j.1365-3040.2006.01531.x

9. Wu L, Zhang Z, Zhang H, Wang XC, Huang R. Transcriptional modulation of ethylene response factor protein JERF3 in the oxidative stress response enhances tolerance of tobacco seedlings to salt, drought, and freezing. Plant Physiol. 2008;148(4):1953-1963. http:// dx.doi.org/10.1104/pp.108.126813

10. Liu XM, Kim KE, Kim KC, Nguyen XC, Han HJ, Jung MS, et al. Cadmium activates Arabidopsis MPK3 and MPK6 via accumulation of reactive oxygen species. Phytochemistry. 2010;71(5-6):614-618. http://dx.doi.org/10.1016/j.phytochem.2010.01.005

11. Maksymiec W. Effects of jasmonate and some other signalling factors on bean and onion growth during the initial phase of cadmium
Therefore, another important conclusion is that $\mathrm{CoCl}_{2}$ should be used as an ethylene inhibitor with cautions, as it might be difficult to distinguish if the observed effects of $\mathrm{CoCl}_{2}$ are dependent on changes in ethylene production or on the action of Co itself.

action. Biol Plant. 2011;55(1):112-118. http://dx.doi.org/10.1007/ s10535-011-0015-9

12. Yakimova ET, Kapchina-Toteva VM, Laarhoven LJ, Harren FM, Woltering EJ. Involvement of ethylene and lipid signalling in cadmiuminduced programmed cell death in tomato suspension cells. Plant Physiol Biochem. 2006;44(10):581-589. http://dx.doi.org/10.1016/j. plaphy.2006.09.003

13. Asgher M, Khan NA, Khan MIR, Fatma M, Masood A. Ethylene production is associated with alleviation of cadmium-induced oxidative stress by sulfur in mustard types differing in ethylene sensitivity. Ecotoxicol Env Saf. 2014;106:54-61. http://dx.doi.org/10.1016/j. ecoenv.2014.04.017

14. Serek M, Woltering EJ, Sisler EC, Frello S, Sriskandarajah S. Controlling ethylene responses in flowers at the receptor level. Biotech Adv. 2006;24(4):368-381. http://dx.doi.org/10.1016/j. biotechadv.2006.01.007

15. Marschner H. Mineral nutrition of higher plants. 2nd ed. London: Academic Press; 1995.

16. Palit S, Sharma A, Talukder G. Effects of cobalt on plants. Bot Rev. 1994;60(2):149-181. http://dx.doi.org/10.1007/BF02856575

17. Hasen SA, Hayat S, Wani AS, Ahmed A. Establishment of sensitive and resistant variety of tomato on the basis of photosynthesis and antioxidative enzymes in the presence of cobalt applied as shotgun approach. Braz J Plant Physiol. 2011;23:175-185.

18. Jaleel CA, Jayakumar K, Chang-Xing Z, Azooz MM. Antioxidant potentials protect Vigna radiata (L.) Wilczek plants from soil cobalt stress and improve growth and pigment composition. Plant Omics. 2009;2(3):120-126.

19. Rastgoo L, Alemzadeh A. Biochemical responses of Gouan (Aeluropus littoralis) to heavy metal stress. Aust J Crop Sci. 2011;5:375-383.

20. Yıldız M, Ciğerci İH, Konuk M, Fatih Fidan A, Terzi H. Determination of genotoxic effects of copper sulphate and cobalt chloride in Allium cepa root cells by chromosome aberration and comet assays. Chemosphere. 2009;75(7):934-938. http://dx.doi.org/10.1016/j. chemosphere.2009.01.023

21. Chmielowska J, Deckert J. Activity of peroxidases and phenylalanine ammonia-lyase in lupine and soybean seedlings treated with copper and an ethylene inhibitor. Biol Lett. 2008;45:59-67.

22. Lehotai N, Pető A, Bajkán S, Erdei L, Tari I, Kolbert Z. In vivo and in situ visualization of early physiological events induced by heavy metals in pea root meristem. Acta Physiol Plant. 2011;33(6):2199-2207. http://dx.doi.org/10.1007/s11738-011-0759-z

23. Cristescu SM, De Martinis D, te Lintel Hekkert S, Parker DH, Harren FJM. Ethylene production by Botrytis cinerea in vitro and in tomatoes. Appl Env Microbiol. 2002;68(11):5342-5350. http://dx.doi. org/10.1128/AEM.68.11.5342-5350.2002

24. Pfaffl MW. A new mathematical model for relative quantification in real-time RT-PCR. Nucl Acids Res. 2001;29(9):45e-45. http://dx.doi. org/10.1093/nar/29.9.e45

25. Zhao S, Fernald RD. Comprehensive algorithm for quantitative realtime polymerase chain reaction. J Comput Biol. 2005;12(8):1047-1064. http://dx.doi.org/10.1089/cmb.2005.12.1047

26. Ahmad P, Ozturk M, Gucel S. Oxidative damage and antioxidants induced by heavy metal stress in two cultivars of mustard (Brassica juncea L.). Fresen Env Bull. 2012;12:2953-2961.

27. Dhankhar R, Solanki R. Effect of copper and zinc toxicity on physiological and biochemical parameters in Vigna mungo (L.) Hepper. Int J Pharma Bio Sci. 2011;2:553-565.

28. Chang C, Wang B, Shi L, Li Y, Duo L, Zhang W. Alleviation of salt stress-induced inhibition of seed germination in cucumber 
(Cucumis sativus L.) by ethylene and glutamate. J Plant Physiol. 2010;167(14):1152-1156. http://dx.doi.org/10.1016/j.jplph.2010.03.018

29. Koehl J, Djulic A, Kirner V, Nguyen TT, Heiser I. Ethylene is required for elicitin-induced oxidative burst but not for cell death induction in tobacco cell suspension cultures. J Plant Physiol. 2007;164(12):15551563. http://dx.doi.org/10.1016/j.jplph.2007.05.012

30. Locke JM. Contrasting effects of ethylene perception and biosynthesis inhibitors on germination and seedling growth of barley (Hordeum vulgare L.). J Exp Bot. 2000;51(352):1843-1849. http://dx.doi.org/10.1093/ jexbot/51.352.1843

31. Santana-Buzzy N, Canto-Flick A, Iglesias-Andreu LG, MontalvoPeniche MC, López-Puc G, Barahona-Pérez F. Improvement of in vitro culturing of habanero pepper by inhibition of ethylene effects. HortScience. 2006;41(2):405-409.

32. Tamimi SM, Timko MP. Effects of ethylene and inhibitors of ethylene synthesis and action on nodulation in common bean (Phaseolus vulgaris L.). Plant Soil. 2003;257(1):125-131. http://dx.doi. org/10.1023/A:1026280517660

33. Kumar GNM, Knowles NR. Wound-induced superoxide production and PAL activity decline with potato tuber age and wound healing ability. Physiol Plant. 2003;117(1):108-117. http://dx.doi. org/10.1034/j.1399-3054.2003.1170114.x

34. Lavoie M, Fortin C, Campbell PGC. Influence of essential elements on cadmium uptake and toxicity in a unicellular green alga: the protective effect of trace zinc and cobalt concentrations. Env Toxicol Chem. 2012;31(7):1445-1452. http://dx.doi.org/10.1002/etc.1855

35. Agrawal GK, Rakwal R, Iwahashi H. Isolation of novel rice (Oryza sativa L.) multiple stress responsive MAP kinase gene, OsMSRMK2, whose mRNA accumulates rapidly in response to environmental cues. Biochem Biophys Res Commun. 2002;294(5):1009-1016. http://dx.doi. org/10.1016/S0006-291X(02)00571-5

36. Agrawal GK, Tamogami S, Iwahashi H, Agrawal VP, Rakwal R. Transient regulation of jasmonic acid-inducible rice MAP kinase gene ( $\mathrm{Os}$ $B W M K 1)$ by diverse biotic and abiotic stresses. Plant Physiol Biochem. 2003;41(4):355-361. http://dx.doi.org/10.1016/S0981-9428(03)00030-5

37. Jonak C, Nakagami H, Hirt H. Heavy metal stress. Activation of distinct mitogen-activated protein kinase pathways by copper and cadmium. Plant Physiol. 2004;136(2):3276-3283. http://dx.doi. org/10.1104/pp.104.045724

38. Ye Y, Li Z, Xing D. Nitric oxide promotes MPK6-mediated caspase-3-like activation in cadmium-induced Arabidopsis thaliana programmed cell death: NO and MPK6 regulate $\mathrm{Cd} 2^{+}-$ induced PCD. Plant Cell Env. 2013;36(1):1-15. http://dx.doi. org/10.1111/j.1365-3040.2012.02543.x

39. Dguimi HM, Debouba M, Ghorbel MH, Gouia H. Tissue-specific cadmium accumulation and its effects on nitrogen metabolism in tobacco (Nicotiana tabaccum, Bureley v. Fb9). CR Biol. 2009;332(1):58-68.
40. Gill SS, Khan NA, Tuteja N. Cadmium at high dose perturbs growth, photosynthesis and nitrogen metabolism while at low dose it up regulates sulfur assimilation and antioxidant machinery in garden cress (Lepidium sativum L.). Plant Sci. 2012;182:112-120. http:// dx.doi.org/10.1016/j.plantsci.2011.04.018

41. Huang H, Xiong ZT. Toxic effects of cadmium, acetochlor and bensulfuron-methyl on nitrogen metabolism and plant growth in rice seedlings. Pestic Biochem Physiol. 2009;94(2-3):64-67. http:// dx.doi.org/10.1016/j.pestbp.2009.04.003

42. Gupta KJ, Fernie AR, Kaiser WM, van Dongen JT. On the origins of nitric oxide. Trends Plant Sci. 2011;16(3):160-168. http://dx.doi. org/10.1016/j.tplants.2010.11.007

43. Chmielowska-Bąk J, Deckert J. A common response to common danger? Comparison of animal and plant signaling pathways involved in cadmium sensing. J Cell Commun Signal. 2012;6(4):191-204. http:// dx.doi.org/10.1007/s12079-012-0173-3

44. Chen F, Wang F, Sun H, Cai Y, Mao W, Zhang G, et al. Genotypedependent effect of exogenous nitric oxide on Cd-induced changes in antioxidative metabolism, ultrastructure, and photosynthetic performance in barley seedlings (Hordeum vulgare). J Plant Growth Regul. 2010;29(4):394-408. http://dx.doi.org/10.1007/s00344-010-9151-2

45. Kopyra M, Stachoń-Wilk M, Gwóźdź EA. Effects of exogenous nitric oxide on the antioxidant capacity of cadmium-treated soybean cell suspension. Acta Physiol Plant. 2006;28(6):525-536. http://dx.doi. org/10.1007/s11738-006-0048-4

46. Chmielowska-Bąk J, Deckert J. Nitric oxide mediates Cd-dependent induction of signaling- associated genes. Plant Signal Behav. 2013;8(12):e26664. http://dx.doi.org/10.4161/psb.26664

47. Besson-Bard A, Gravot A, Richaud P, Auroy P, Duc C, Gaymard F, et al. Nitric oxide contributes to cadmium toxicity in Arabidopsis by promoting cadmium accumulation in roots and by up-regulating genes related to iron uptake. Plant Physiol. 2009;149(3):1302-1315. http://dx.doi.org/10.1104/pp.108.133348

48. Huerta-Ocampo JA, León-Galván MF, Ortega-Cruz LB, BarreraPacheco A, De León-Rodríguez A, Mendoza-Hernández G, et al. Water stress induces up-regulation of DOF1 and MIF1 transcription factors and down-regulation of proteins involved in secondary metabolism in amaranth roots (Amaranthus hypochondriacus L.): proteomic and transcriptomic analysis of amaranth roots under drought stress. Plant Biol. 2011;13(3):472-482. http://dx.doi. org/10.1111/j.1438-8677.2010.00391.x

49. Liao Y, Zou HF, Wei W, Hao YJ, Tian AG, Huang J, et al. Soybean GmbZIP44, GmbZIP62 and GmbZIP78 genes function as negative regulator of $A B A$ signaling and confer salt and freezing tolerance in transgenic Arabidopsis. Planta. 2008;228(2):225-240. http://dx.doi. org/10.1007/s00425-008-0731-3 